\section{Evolving Biology.}

Outlines of Evolutionary Biology. By Prof. Arthur Dendy. With Glossary of Technical Terms. Third edition, revised and enlarged. Pp. xliii $+48 \mathrm{I}$. (London: Constable and Co., Ltd., I923.) I6s. net.

W $\mathrm{E}$ extend a welcome to this revised and enlarged edition of an exceedingly useful book, which has been a favourite since it was first published some ten years ago. It is an introduction to the study of the principles of biology, well thought out by a teacher of experience, who has himself made important contributions to the science. There are five parts, dealing with the following subjects : the structure and functions of organisms and the cell theory; the evolution of sex; variation and heredity; the theory and evidence of organic evolution, with particular insistence on adaptations ; and, finally, the factors of organic evolution. What gives the book its particular merit, in addition to the indispensable qualities of lucidity and good imdement, is its concreteness. Prof. Dendy is always oringing the student into touch with concrete examples which illustrate the principles discussed and enable the reader to get a firmer grip.

There is throughout the book a scientific good humour. Thus when the author is discussing such a thorny question as the transmissibility of individually acquired somatic modifications, he is temperate in his language and judicial in his survey. He does not dogmatise and he does not suggest that the only tenable position is Lamarckian; and yet he is not in the least wobbly, as this quotation may show.

"On the whole, then; the available evidence seems to indicate that suddenly and exceptionally acquired characters, such as mutilations, are occasionally but only rarely inherited to such an extent as to be recognisable, while, on the other hand, characters which are due to the continued action of some external stimulus, extending perhaps over many generations, in the long run become so firmly impressed upon the organism that they affect the germ cells as. well as the somatic cells and thus become truly blastogenic."

We happen to think that this is a misinterpretation of the evidence, but our point is that Prof. Dendy puts the problem before the student in an eminently fairminded fashion.

The author wishes good speed to the investigators of the chemical and physical processes that go on in the living body, but he denies that the formulæ of chemistry and physics can be made to cover all the phenomena of life.

"We may, perhaps, believe that, as living matter became more and more complex in its structure, it entered progressively into new energy relations with its environment, which became more and more unlike those exhibited by inanimate matter, until at length they passed in some respects altogether beyond the reach of chemical and physical explanations."

This appears to us to be, on the whole, the scientific position at present, though the wording is a little suggestive of the idea that mind is a resultant of complexifying proteins and energy-relations, which is absurd, as Euclid used to say when he was tired. Moreover, it is open to question whether there is any "inanimate matter" anywhere. But what we wish to say is this, that if we shared Prof. Dendy's non-mechanistic views, as we do but more also, then we should not entitle a chapter "the mechanism of evolution." The point is that evolution transcends mechanism, and, if that is so, it is a pity to say mechanism when you only mean modus operandi. For there can be no doubt that if one says "mechanism" often enough in reference to vital processes, people will end in believing us, and we shall believe it ourselves!

We have referred only to a crumpled rose-leaf, for we really think that the book is as good as any book has a right to be. It is singularly attractive in every way-beautifully printed, with many interesting illustrations of great interest ; and it is a personal deliverance. Most alteration, naturally, has been made in the part dealing with heredity. There is a valuable glossary, but we think it was a psychological mistake to put it in the forefront of the book. What a thorny hedge to these fair pastures!

\section{Natural History of Pheasants.}

$A$ Monograph of the Pheasants. By William Beebc. In 4 volumes. Vol. 4. Pp. $\mathrm{xv}+242+23$ coloured plates +27 photogravure plates +6 maps. (London: H. F. and G. Witherby, I922.) I $2 l$. ros. net.

THE fourth and final volume of this great Monograph ${ }^{1}$ treats of the golden pheasants (Chrysolophus), the bronze-tailed peacock pheasants (Chalurus), the peacock pheasants (Polyplectron), the ocellated pheasants (Rheinardius), the Argus pheasants (Argusianus), and the peafowl (Pavo).

These groups comprise forms of surpassing beauty of plumage and remarkable habits. The life-histories of a number of the species treated of were previously unknown, since no ornithologist had ever penetrated the remote fastnesses in which their lives are spent, while in the case of others much remained to be learned. Mr. Beebe's researches have lifted the veil which has hitherto masked the ways of many.

To the illustration of the seventeen species and subspecies here described, twenty-two coloured plates

1 Previous notices relating to this Monograph appeared in NATURE, vol. ro2, p. 302 ; vol. 107, p. 235 ; and vol. 110, p. 105.

No. 28 I 6 , VOL. I 12$]$ 